Article

\title{
Estimation of Peak Flow in Ungauged Catchments Using the Relationship between Runoff Coefficient and Curve Number
}

\author{
Nam Won Kim ${ }^{1, *}$ and Mun-Ju Shin ${ }^{2, *}$ \\ 1 Water Resources \& River Research Institute, Korea Institute of Civil Engineering and Building Technology, \\ 283, Goyangdae-ro, Ilsanseo-gu, Goyang-si, Gyeonggi-do 10223, Korea \\ 2 Water Resources Research Team, Jeju Province Development Corporation, 1717-35, Namjo-ro, Jocheon-eup, \\ Jeju-si, Jeju-do 63345, Korea \\ * Correspondence: nwkim@kict.re.kr (N.W.K.); mj.shin@hotmail.com (M.J.-S.); \\ Tel.: +82-(0)31-9100-256 (N.W.K.); +82-(0)10-5955-3601 (M.J.-S.); Fax: +82-(0)31-9100-251 (N.W.K.)
}

Received: 22 October 2018; Accepted: 13 November 2018; Published: 16 November 2018

check for updates

\begin{abstract}
Hourly flood flow estimation for gauged and ungauged catchments is a prerequisite for planning and water management. Various methods have been applied in a multitude of studies to calculate the peak flow for ungauged catchments. However, it is not simple for engineers to use the existing methods in practical applications. An easier method is suggested for this purpose in this study. The authors estimated the relationship between the runoff coefficient, intensity of rainfall, and curve number, and then utilized the relationship to calculated the peak flow using the rational method for ungauged catchments. Rainfall and flood time series for ungauged study catchments were generated by a simple data generation method and a distributed rainfall-runoff model. Results showed that the runoff coefficients simulated using the estimated relationship reasonably agree with the runoff coefficients in the studied ungauged catchments. In addition, the peak flow simulated using the rational method and the relationship highly agree with the peak flow in the ungauged catchments. Therefore, the peak flow in ungauged catchments can be easily calculated by this method, which is more pragmatic for engineers.
\end{abstract}

Keywords: runoff coefficient; curve number; distributed rainfall-runoff model; flood-intensity-duration curve; peak flow simulation

\section{Introduction}

Flood estimation with an hourly time step is a prerequisite for planning and water management [1]. However, many catchments are ungauged; therefore, there are limitations for flood calculation using rainfall-runoff models [1,2]. Flood estimation still can be conducted for ungauged catchments through regionalization methods either using (1) gauged catchment data with hydrologically similar areas [3-5] or (2) using catchment attributes of ungauged catchments [6-10]. However, the regionalization method has issues. It is difficult to determine the hydrological similarity of the catchment, and the parameters should be updated whenever land-use changes [11]. In addition, physically similar catchments cannot be easily assumed as being hydrologically similar for many catchments [12].

In order to overcome these shortcomings, geomorphological instantaneous unit hydrographs (GIUH) [13] have been applied [11]. Bhaskar et al. [2] used geomorphological characteristics of catchments to derive GIUH, which were then applied to Jira catchment in India to simulate 12 flood events. They found that the peak flows were properly simulated for ungauged catchments with a reasonable amount of errors in the peak flow and time to peak. Jain et al. [14] estimated the design 
flood by applying GIUH to the Gambhiri dam catchment in India and found that the characteristics of the peak flow of the design flood were sensitive to various storm patterns. They also proposed that this method can be used to estimate the design flood of ungauged catchment. Kumar et al. [15] developed GIUH-based Clark and Nash models and simulated direct surface runoff hydrographs for the Ajay catchment in India. They obtained satisfactory simulation results of hydrographs by treating a gauged catchment as an ungauged catchment.

In another study using physical characteristics of catchments, Cole and Moore [16] used the grid-to-grid (G2G) model, a topography-driven distributed rainfall-runoff model, to simulate streamflow at $15 \mathrm{~min}$ intervals using spatiotemporally distributed radar rainfall data. They simulated flows of sub-catchments (treated as ungauged areas) by utilizing the model's calibrated parameters that were optimized for the observed outlet streamflow data. The G2G model's ungauged catchment streamflow simulation modeled the observed streamflow very well. Smith et al. [17] simulated the continuous hourly runoff over a 10-year period of various catchments using the catchment's topography, land-use, soil characteristics, and spatiotemporal distribution of rainfall in 14 distributed rainfall-runoff models for the Distributed Model Intercomparison Project (DMIP). In this work, calibrated distributed models properly simulated the observed flow at sub-catchments (treated as ungauged areas) in general as well as at the catchment outlets.

Despite the good model performances in the aforementioned studies, most methods are too complex for practical engineering applications. This study presents a simpler method to calculate peak flows in ungauged catchments for practical engineering uses. Peak flow is related to spatiotemporal distribution and intensity of rainfall, time of concentration (TC), and curve number (CN) [18], all of which explain the characteristics of given catchments. The TC is the time taken for the water from the most hydrologically remote location to reach the catchment's outlet [19]. The well-known rational method [20] calculates peak flow using rainfall intensity, runoff coefficient, and catchment area. Therefore, engineers can alternately calculate the peak flow for ungauged catchments using the rational method and information on rainfall, $\mathrm{TC}$, and $\mathrm{CN}$ as far as the relationship between the runoff coefficient, rainfall, and $\mathrm{CN}$ is defined. McCuen and Bondelid [21] investigated the relationship between the runoff coefficient and $\mathrm{CN}$; however, they did not calculate peak flows using this relationship.

This study aims, first, to investigate the relationship between the runoff coefficient, rainfall, and $\mathrm{CN}$ for ungauged catchments. In order to calculate the runoff coefficient for ungauged catchments, hydrographs of the catchments are required. The authors employed the spatial data extension (SDE) method [22] to generate hourly runoff hydrographs for ungauged catchments. Different from previous studies (e.g., [16,17]), the SDE method optimizes the physical parameters of the rainfall-runoff model using multiple flood events to obtain more reliable parameter values, which are used for flood calculation in ungauged catchments. Second, it aims to calculate the peak flows in ungauged catchments using the rational method and the estimated relationship. This means that the peak flow of other events in the future in ungauged catchments can be easily calculated using the estimated relationship and the rational method without involving complex simulation processes each time. Therefore, the aims of this study are to (1) estimate the relationship between the runoff coefficient, rainfall and $\mathrm{CN}$ using generated ungauged catchment hourly hydrographs and (2) provide an easy way to calculate the hourly peak flows of other events in the future using the developed relationship. Note that the runoff coefficient and $\mathrm{CN}$ have different origins, but they have the same conceptual meaning.

Section 2 describes the catchments, input data, objective function, performance evaluation statistics, and rainfall-runoff model used in this study. Section 3 explains the methodology and Section 4 provides the results and discussion. The conclusions are summarized in Section 5. 


\section{Study Area and Materials}

\subsection{Catchment and Input Data}

The study area is the Andongdam catchment $\left(1584 \mathrm{~km}^{2}\right)$ located in the eastern part of South Korea (Figure 1). This mountainous dam catchment includes a large reservoir that secures water for domestic, industrial and agricultural use. The reservoir is also designed for downstream flood flow control. This catchment is composed of $1.4 \%$ urban area, $11.9 \%$ agricultural area, $82.2 \%$ forest, $2.1 \%$ grassland and $2.4 \%$ water area. Hydrologic soil groups of this catchment consist of $0.8 \%$ group A, $17.2 \%$ group $B, 5 \%$ group $C$ and $77 \%$ group $D$. The drainage characteristics of the soil in this catchment consist of $78.6 \%$ very good, $13.5 \%$ good, and $7.9 \%$ bad. This study utilized hourly observed streamflow at three gauge locations (Andongdam, Dosan, and Socheon) for calibration and validation of model parameters. The authors converted the water level and rating data from the Water Resources Management Information System (www.wamis.go.kr) into the observed flow data.

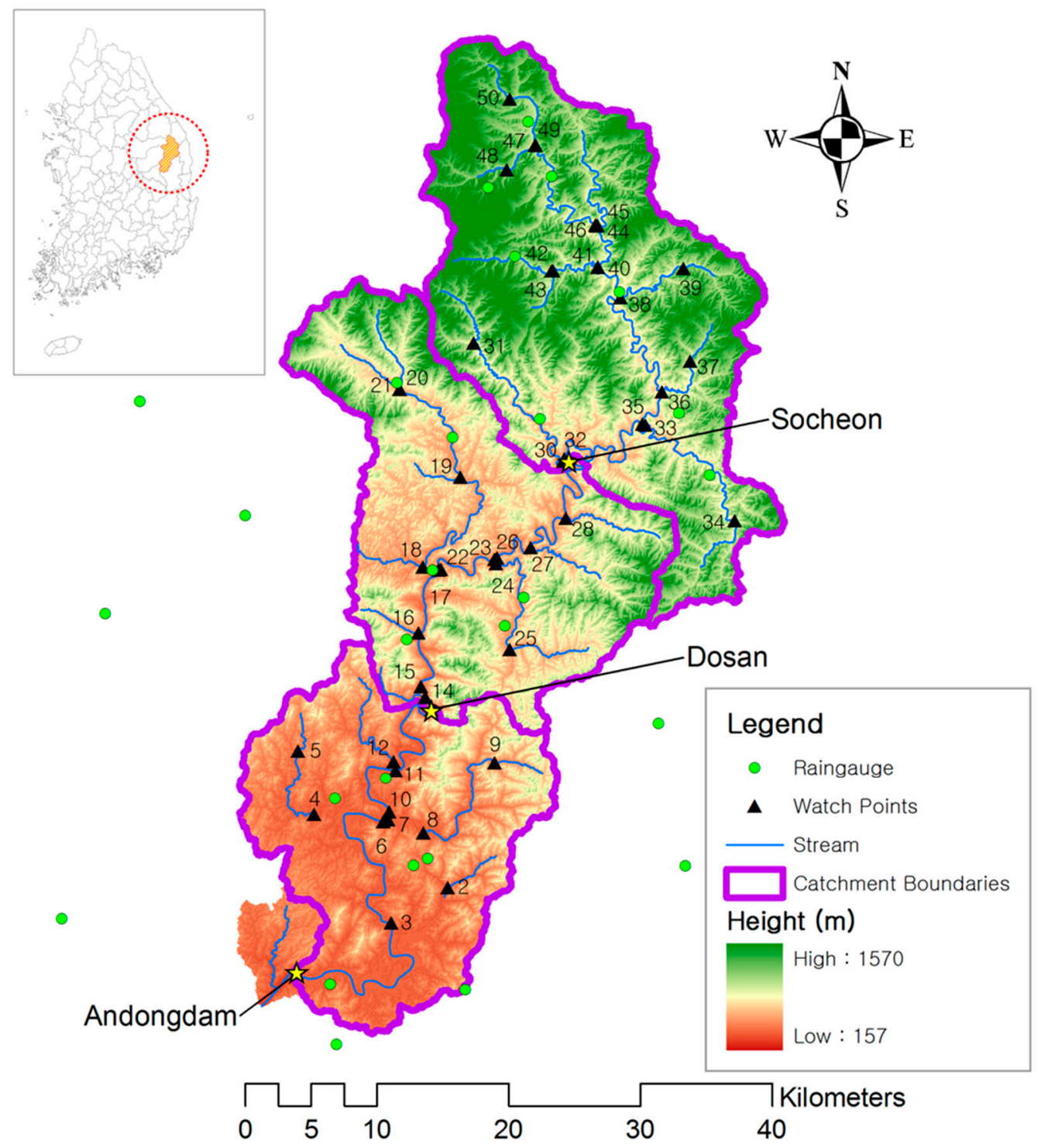

Figure 1. Location and topography of the Andongdam catchment in the Republic of Korea. The yellow stars represent the water level gauging stations. The watch point is the location at which the simulation output is extracted in time series. 
The databases from three organizations were used for the climate input for the distributed rainfall-runoff model to simulate the flood flows (Korea Meteorological Administration, http://www.kma.go.kr; Ministry of Land, Infrastructure, and Transport, www.molit.go.kr; and K-water, www.kwater.or.kr). The authors used hourly rainfall data from up to 27 rainfall gauge stations within and near the Andongdam catchment (Figure 1). A total of 20 rainfall events, which have relatively large magnitudes, long durations, and reflect the monsoon climate, were selected for the period from 1998 to 2009 (Table A1). These events were chosen for quality purposes while a total of 31 years of records (1980-2010) is available with more missing data. Ordinary kriging was used to convert hourly rainfall records into the grid rainfall data (resolution $200 \mathrm{~m} \times 200 \mathrm{~m}$ ) for distributed rainfall-runoff model simulation. The ordinary kriging method was used because it can adequately represent the spatial distribution of rainfall.

A land use map, soil map, and digital elevation model (DEM; scale 1:25,000) were converted into grid form with a resolution of $200 \mathrm{~m} \times 200 \mathrm{~m}$ for the physical inputs of the distributed rainfall-runoff model. Therefore, the distributed rainfall-runoff model utilizes the spatial variability of the physical catchment characteristics as well as the spatiotemporal variability of rainfall.

\subsection{Objective Function and Performance Evaluation Statistics}

The Nash-Sutcliffe Efficiency (NSE) [23], which has been widely used in rainfall-runoff modeling, was selected as the objective function for the parameter calibration:

$$
\mathrm{NSE}=1-\frac{\sum_{i=1}^{n}\left(Q_{o b s, i}-Q_{s i m, i}\right)^{2}}{\sum_{i=1}^{n}\left(Q_{o b s, i}-\overline{Q_{o b s}}\right)^{2}}
$$

where $Q_{o b s, i}$ is the observed flow at the time step $i$ (hourly), $\overline{Q_{o b s}}$ is the mean of the observed flow, $Q_{s i m, i}$

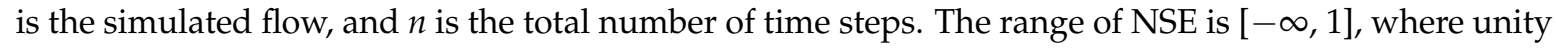
represents the perfect match between the observed and simulated flow. The NSE emphasizes the high flow fit due to the squared differences between the observed and simulated values [24,25]; therefore, this objective function is appropriate for this study, which focuses on fitting hydrographs of flood.

We select three model performance evaluation statistics: the NSE; percent bias (PBIAS); and modified correlation coefficient $\left(r_{\text {mod }}\right.$; [26]). The use of NSE was recommended by the American Society of Civil Engineers (ASCE) [27] and provides the overall quality of flow simulations [28]. The use of PBIAS was recommended in Smith et al. [29] for the evaluation of the simulated flow and shows poor model performance in percentage terms with respect to the volume of the simulated flow [30]. The best PBIAS value is zero, because it represents zero difference between the simulated and observed flow. Positive PBIAS values represent overestimation of simulated flows.

$$
\text { PBIAS }=\frac{\sum_{i=1}^{n}\left(Q_{\text {sim }, i}-Q_{o b s, i}\right)}{\sum_{i=1}^{n} Q_{o b s, i}} \times 100
$$

The usefulness of $r_{\text {mod }}$ in the model evaluation was demonstrated in Smith et al. [17]. The $r_{\text {mod }}$ value complements the shortcomings of the correlation coefficient, namely, the significant influence from outliers and insensitivity to the differences in volumes [26]. The correlation coefficient is:

$$
r=\frac{n \sum_{i=1}^{n} Q_{s i m, i} Q_{o b s, i}-\sum_{i=1}^{n} Q_{s i m, i} \sum_{i=1}^{n} Q_{o b s, i}}{\sqrt{\left[n \sum_{i=1}^{n} Q_{s i m, i}{ }^{2}-\left(\sum_{i=1}^{n} Q_{s i m, i}\right)^{2}\right]\left[n \sum_{i=1}^{n} Q_{o b s, i} i^{2}-\left(\sum_{i=1}^{n} Q_{o b s, i}\right)^{2}\right]}}
$$

The standard deviations of the simulated and observed flows are:

$$
\sigma_{\text {sim }}=\sqrt{\frac{\sum_{i=1}^{n}\left(Q_{\text {sim }, i}-\overline{Q_{\text {sim }}}\right)^{2}}{n-1}}
$$




$$
\sigma_{o b s}=\sqrt{\frac{\sum_{i=1}^{n}\left(Q_{o b s, i}-\overline{Q_{o b s}}\right)^{2}}{n-1}}
$$

Finally, the modified correlation coefficient is:

$$
r_{\text {mod }}=r \frac{\min \left\{\sigma_{\text {sim }}, \sigma_{o b s}\right\}}{\max \left\{\sigma_{\text {sim }}, \sigma_{o b s}\right\}}
$$

The authors set the thresholds of the satisfactory model performance statistics as: NSE >0.5 [28], PBIAS $\pm 30 \%$, and $r_{\text {mod }}>0.6$. Smith et al. [17] reported with various rainfall-runoff simulations, including the distributed rainfall-runoff models, that the PBIAS values, except for outliers, were placed within these thresholds and $r_{\text {mod }}$ values were mostly greater than 0.6 for model calibrations.

\subsection{Grid-Based Rainfall-Runoff Model}

The grid-based rainfall-runoff model (GRM) [31], which is a physically based distributed rainfall-runoff model with hourly time steps, was employed in this study. This model is designed to handle the characteristics of Korean catchments. It simulates surface flow, infiltration, subsurface flow, baseflow, and the impact of flow control facilities (Figure 2). The kinematic wave model is used to calculate surface flow, which is composed of overland flow and channel flow. The overland flow occurs by infiltration excess flow [32] and saturation excess flow [33]. Infiltration in the upper soil layer is calculated using the Green-Ampt model, and the infiltrated water becomes subsurface flow. If the downstream area of the subsurface flow is a stream, the subsurface flow becomes a lateral subsurface flow that flows into the lateral direction of the stream. If the downstream area of the subsurface flow is a surface saturated with water, the subsurface flow is returned as an overland flow [34]. The lateral baseflow in the lower soil layer is calculated using Darcy's law [35]. The total flow is the sum of overland flow, channel flow, lateral subsurface flow, and lateral base flow. The GRM has 12 parameters (Table A2). The parameter ranges were suggested by Choi [36]. The spatial resolution of the GRM simulation was set to $200 \mathrm{~m} \times 200 \mathrm{~m}$; the size of the grid meets the requirements of Bathurst [37], who argued that a single grid area should cover less than $1 \%$ of the catchment area. The governing equations of the GRM are as follows:

$$
\begin{gathered}
\frac{\partial h}{\partial t}+\frac{\partial q}{\partial x}=r-f+\frac{q_{r}}{\Delta y} \\
\frac{\partial A}{\partial t}+\frac{\partial Q}{\partial x}=r \Delta y+q_{L}+q_{s s}+q_{b} \\
S_{0}=S_{f}
\end{gathered}
$$

where $h$ is flow depth, $q(q=u h)$ is flow rate per unit width, $u$ is overland flow velocity in $x$ direction, $r$ is rainfall intensity, $f$ is infiltration rate, $q_{r}$ is return flow into the overland flow, $\Delta y$ is the width of control volume, $A$ is channel cross-sectional area, $Q$ is discharge in the channel, $q_{L}$ is lateral flow from overland flow, $q_{s s}$ is subsurface flow, $q_{b}$ is baseflow, $S_{0}$ is surface slope, and $S_{f}$ is friction slope. A more detailed description of the GRM can be found in Choi and Kim [38]. 


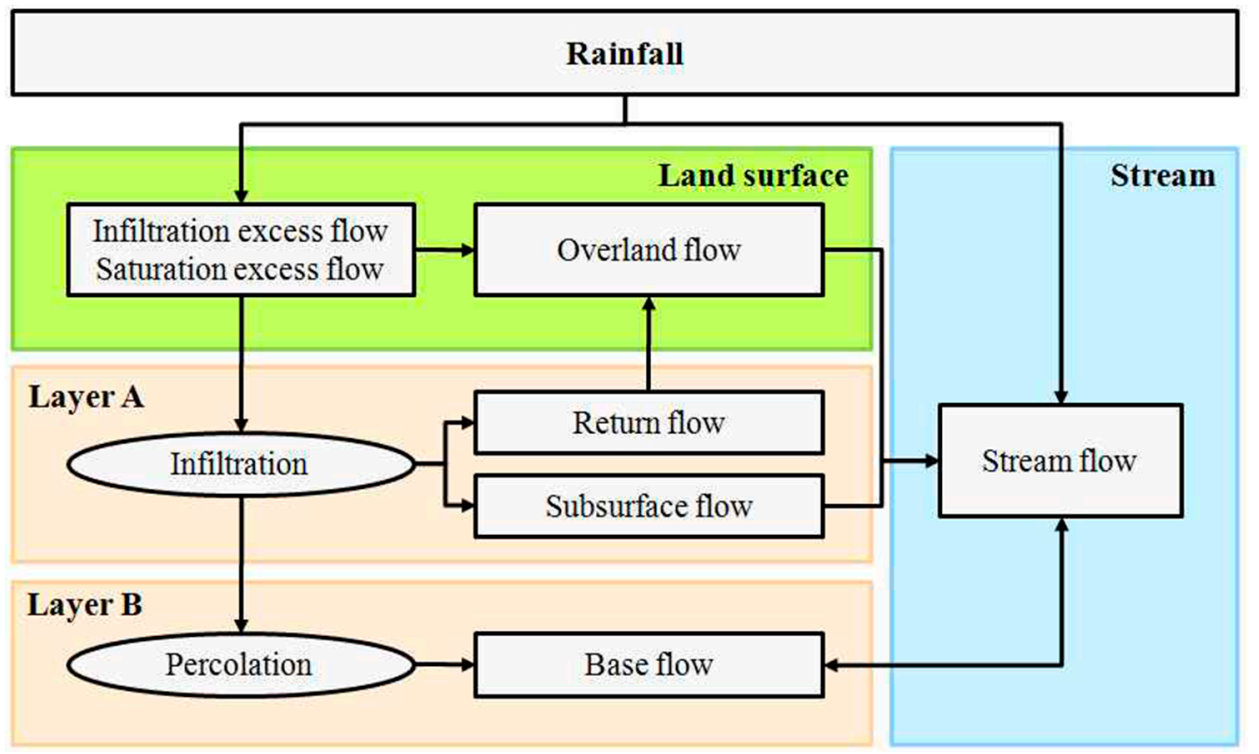

Figure 2. Schematic diagram of the grid-based rainfall-runoff model (GRM) (taken from [38]).

\section{Methods}

\subsection{Parameter Calibration and Flow Simulation in Ungauged Catchments}

The SDE method, which is a simple data generation method for ungauged catchments, generates hourly flood hydrographs using the GRM by applying calibrated parameters of gauged catchments. This method is based on the hypothesis that the simulated flow at each upstream grid point is reasonable so long as the simulated model flow at the catchment outlet, which is the aggregation of the routed flows of all upstream grid points, is equal to the observed flow. The flood hydrographs for the ungauged catchments of interest can therefore be generated with this method, which is more efficient and pragmatic compared to the DMIP method [17]. Note that it is a special case of regionalization because this method is used to transfer information from downstream gauging stations to upstream ungauged catchments.

For the implementation of this method, the calibrated parameters related to the physical catchment characteristics, which are the parameters No. 2 to No. 5 (Table A2), should be reliable for all events, regardless of the storm characteristics, because the storm characteristics do not influence the physical characteristics of the catchments. Therefore, the authors optimized the physical parameters for all events simultaneously using the NSE objective function to obtain consistent physical parameter values. Theoretically, physical parameters are uniquely determined by the characteristics of a given catchment, therefore, they do not need calibration. However, usually, the parameters are still calibrated because of problems of measurement errors, scale difference between the model grid and the measurement data, and lack of data used to extract the parameter values [39-43]. After the calibration of the physical parameters, the initial soil saturation ratio (parameter No. 1 in Table A2) was optimized for each event because this parameter depends on the antecedent soil moisture condition for the respective event. The regional calibration method [44] has a key idea similar to the calibration method of this study. However, the regional calibration method optimizes the parameters for multiple catchments simultaneously. It is worth noting that the GRM simulation considers the physical spatial variability by using the physical input datasets (see Section 2.1). The consistent physical parameter values are used as the minimum thresholds. This simultaneous multi-event calibration method uses all possible historical event data for a selected calibration catchment to generate data for ungauged catchments. Therefore, this method is different from the split-sample test [45] that uses distinct data series in the same catchment for validation. Instead, this method validates the calibrated parameters using historical events in the other dependent upstream gauged catchments (validation catchments), which are 
assumed to be ungauged catchments. Good simulated results in the validation catchments implies that the hypothesis of this method is validated, and these calibrated parameter values can be applied to the actual upstream ungauged catchments for the generation of flood hydrographs. Therefore, this method is a special case of the parameter calibration and validation method for regionalization.

For the GRM parameter calibration in the Andongdam catchment (see Figure 1), two sub-catchments (Dosan and Socheon), which are assumed to be ungauged catchments, were used for the validation. Three performance evaluation statistics (NSE, PBIAS, and $r_{\text {mod }}$ ) were calculated for the model calibration and validation. The authors selected an additional 47 ungauged catchments (Table A3) and generated the hourly flood hydrographs using the calibrated parameter values. In addition, the areal rainfall time series for all 50 catchments were calculated using the grid rainfall data (see Section 2.1). The simulated flood hydrographs and areal rainfall time series for the 50 catchments are used to generate two intensity-duration curves in Section 3.2.

\subsection{Calculation of Important Factors Using the Rainfall-Intensity-Duration Curve (RIDC) and Flood-Intensity-Duration Curve (FIDC)}

The flood-intensity-duration curve (FIDC; Figure 3) for 50 catchments was generated with the flood-duration-frequency (QDF) method [46,47] using the simulated flood hydrographs. The QDF method calculates the average flow with a moving average technique for different durations and calculates the frequency of the maximum flows among the averaged flows for different durations [48,49]. This method was employed in various studies [50-54]. The authors used the maximum flows for different durations (e.g., $1 \mathrm{~h}$ and $2 \mathrm{~h}$ ) to generate the FIDC by plotting the maximum flows against the durations. Frequency analysis is not conducted because it is beyond the scope of this study. The rainfall-intensity-duration curve (RIDC) for the 50 catchments was generated with the traditional intensity-duration-frequency (IDF) method, which is similar to the QDF method but uses the areal rainfall time series as input. Note that the GRM utilizes the grid rainfall datasets as inputs to simulate the flood hydrographs, but we calculated the areal rainfall time series for each catchment to generate the RIDC. The unit for the FIDC and RIDC is $\mathrm{mm} / \mathrm{h}$. The effect of the point to grid rainfall conversion on the GRM simulation results is not studied because it is also beyond the scope of this study.

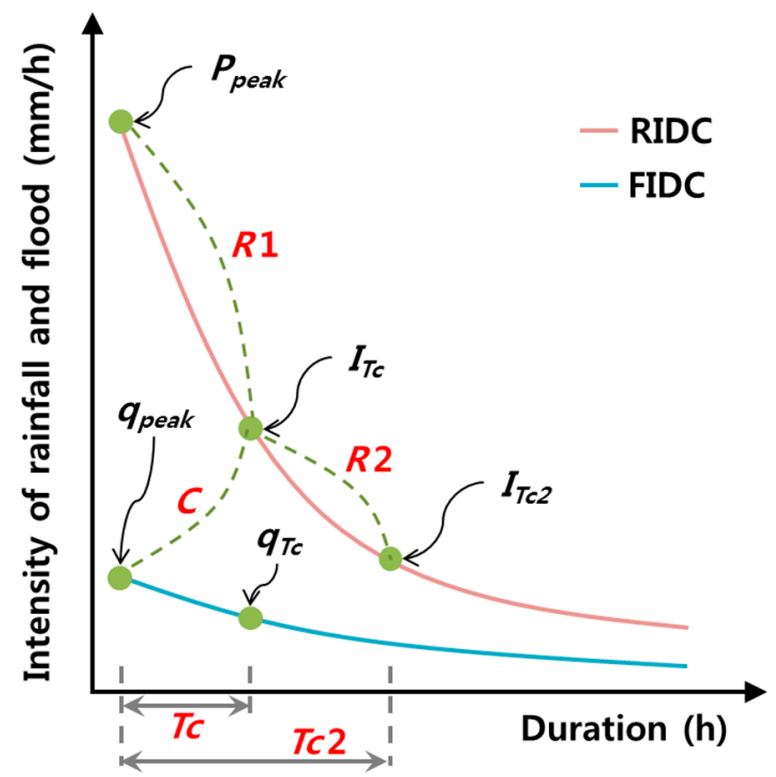

Figure 3. Schematic plot for the calculation of the runoff coefficient $(C)$ and rainfall intensity ratios ( $R 1$ and $R 2) ; T_{\mathcal{C}}$ is the time of the concentration in hour; $T_{c} 2$ is TC multiplied by two; $C$ is the ratio between the flood peak $\left(q_{\text {peak }}\right)$ and the mean rainfall intensity during TC $\left(I_{T c}\right) ; R 1$ is the ratio between the rainfall peak $\left(P_{\text {peak }}\right)$ and $I_{T c}$; and $R 2$ is the ratio between $I_{T c}$ and the mean rainfall intensity during two TCs $\left(I_{T c 2}\right)$. FIDC and RIDC are flood-intensity-duration curve and rainfall-intensity-duration, respectively. 
The factors important for the calculation of the peak flow in ungauged catchments are the runoff coefficient $(C)$, rainfall intensity ratios $(R 1$ and $R 2)$, and $C N$. The rational method's $C$, which is an indicator of the storm effect on the flood response in the catchments, can be calculated using the RIDC, FIDC, and the TC. Note that this study did not use the rational method to calculate the peak flow but used the concept of this method to calculate $C$. The rational method is given as:

$$
Q_{\text {peak }}=C I_{T c} A
$$

where $Q_{\text {peak }}$ is the peak flow, $I_{T c}$ is the mean rainfall intensity for the TC $(\mathrm{mm} / \mathrm{h})$, and $A$ is the size of the catchment. The authors used the TC equation of Kim [55], which is suitable for the Korean catchments:

$$
T c=0.76 A^{0.38}
$$

Boyd [56] and D'Odorico and Rigon [57] suggested a similar form of Equation (11) and demonstrated the suitability of the equation, even though it has only one variable, which is catchment area. $C$ is calculated as:

$$
C=\frac{q_{p e a k}}{I_{T c}}
$$

where the specific peak flow $q_{\text {peak }}(\mathrm{mm} / \mathrm{h})$ is calculated as $Q_{\text {peak }}$ divided by $A$. Therefore, $C$ reflects the effect of the mean rainfall intensity during the TC on the peak flow. Figure 3 illustrates this idea, where $T c$ represents the time of concentration.

The temporal variation of the rainfall intensity could affect the peak flow. Therefore, the authors calculated the two rainfall intensity ratios $R 1$ and $R 2$ :

$$
\begin{array}{r}
R 1=\frac{P_{\text {peak }}}{I_{T c}} \\
R 2=\frac{I_{T c 2}}{I_{T c}}
\end{array}
$$

where $P_{\text {peak }}$ is the peak rainfall intensity; $T_{c} 2$ represents two times the TC value; $I_{T c 2}$ is the mean rainfall intensity during $T_{c} 2(\mathrm{~mm} / \mathrm{h}) ; R 1$ represents a variation of the rainfall intensity between $P_{\text {peak }}$ and $I_{T c} ; R 2$ represents the variation of the rainfall intensity between $I_{T c}$ and $I_{T c 2} ;$ and $R 1$ and $R 2$ explain whether a storm is either intense over a short time or a longer time. For example, the gradient of the RIDC is steep when a storm is characterized by large intensity with a short duration; therefore, the value of $R 1$ becomes large.

The $\mathrm{CN}$ [58] can be calculated using the potential maximum retention $(S)$ in $\mathrm{mm}$ :

$$
\mathrm{CN}=\frac{1000}{10+\frac{S}{25.4}}
$$

Hawkins [59] suggested Equation (16) to calculate the $S$ if the initial loss is $20 \%$ of $S$, which was used in the U.S. Department of Agriculture, Natural Resources Conservation Service USDA-NRCS to develop the curve number method. 


$$
S=5\left[\left(P_{v o l}+2 Q_{v o l}\right)-\sqrt{Q\left(4 Q_{v o l}+5 P_{v o l}\right)}\right],
$$

where $P_{v o l}$ and $Q_{v o l}$ are the volumes of rainfall and flow in $\mathrm{mm}$, respectively. The rainfall and flow volumes can be calculated using the product of the intensities from RIDC and FIDC and the durations. For example, $P_{v o l}$ is the product of $I_{T c}$ and TC, whereas $Q_{v o l}$ is the product of $q_{T c}$ and TC, and $q_{T c}$ is the mean flood intensity over TC (Figure 3). Given the Equations (15) and (16) for $\mathrm{CN}$ and $S$, respectively, the $\mathrm{CN}$ can therefore be calculated from the TC using the rainfall and flow volume.

3.3. Analysis of the Relationship between the Important Factors, and Simulation of the Peak Flow Using the Relationship

$Q_{v o l}, P_{v o l}$, and $S$ have the following relationship [58]:

$$
Q_{v o l}=\frac{\left(P_{v o l}-0.2 S\right)^{2}}{P_{v o l}+0.8 S}
$$

The runoff ratio $\left(C_{r}\right)$ can be calculated using $P_{v o l}$ and $\mathrm{CN}$ :

$$
C_{r}=\frac{Q_{v o l}}{P_{v o l}}=\frac{\left[P_{v o l}-0.2\left(\frac{25400}{\mathrm{CN}}-254\right)\right]^{2}}{P_{v o l}\left[P_{v o l}+0.8\left(\frac{25400}{\mathrm{CN}}-254\right)\right]}
$$

The runoff coefficient $C$ can be expressed as a function of $C_{r}, R 1, R 2$, and $C N$ in the analysis of the relationship between $C, C_{r}, R 1, R 2$, and $\mathrm{CN}$ :

$$
C \sim f\left(C_{r}, R 1, R 2, \mathrm{CN}\right)
$$

The authors used stepwise multiple regression to estimate the relationship. Finally, the simulated $q_{\text {peak }}\left(q_{\text {peak_sim }}\right)$ can be calculated using the rational method, Equation $(10)$, and the simulated $C\left(C_{\text {sim }}\right)$, which is calculated by the Equation (19):

$$
q_{p e a k \_s i m}=C_{\text {sim }} I_{T c}
$$

Equation (20) shows that the peak flow in the ungauged catchments can be calculated using the rainfall time series, $\mathrm{CN}$, and the relationship for $\mathrm{C}$. It means that the peak flow of the ungauged catchment can be calculated conveniently using Equation (20) without repeatedly conducting hydrological simulation. Note that $C_{r}$ is a function of the $P_{v o l}$ and $\mathrm{CN}$ as shown in Equation (18); therefore, $P_{v o l}$ and $\mathrm{CN}$ are used for the calculation of $C_{\text {sim }}$ instead of using $C_{r}$. The complete flow of the research method is summarized in Figure 4. 


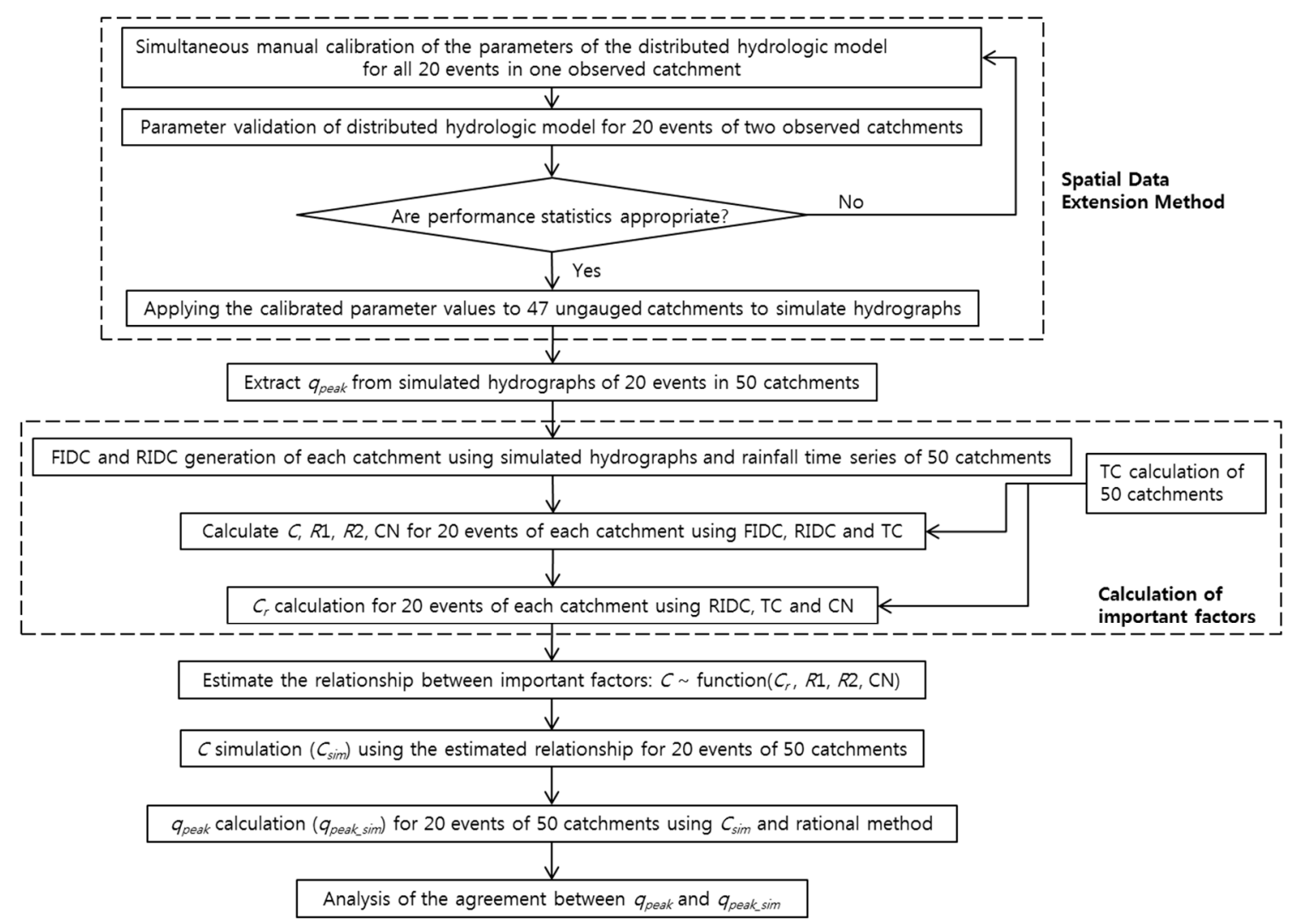

Figure 4. Flow chart for research method.

\section{Results and Discussion}

\subsection{Model Performance}

Figure 5 shows the performance of the GRM, and the acceptance boundaries for the three model performance statistics mentioned in Section 2.2 are shown in black dashed lines. The simulations of the Andongdam catchment shows satisfactory performance statistics for the 20 events (Figure 5). Figure 6 shows the selected three simulated hydrographs of the Andongdam catchment that simulated the observed hydrographs relatively well. The simulations of the validation catchments Dosan and Socheon display reasonable performance results, except for some events. The PBIAS value of the 2000_Evt1 event in the Dosan catchment indicates that the NSE value, which is very close to the acceptance boundary, is acceptable while the simulated flow was slightly overestimated. The $r_{\bmod }$ is also satisfactory; therefore, the authors determined that the simulated flow for this event was acceptable. The model performance for Socheon catchment events was examined in the same way. All three performance evaluation statistics were unsatisfactory with the 2004_Evt1 event. The reason for this could be the water level measurement error, rather than the error in the GRM itself or climate input data, because the results from the other events for the Socheon catchment were acceptable with the same model structure. In addition, the results for the Andongdam and Dosan catchments for the 2004_Evt1 event were all reasonable with the same input rainfall data used for the Socheon catchment. It is worth noting that we investigated the observed flow of the Socheon catchment and found no outliers or anomalies. Therefore, the authors determined that the simulated flow for the 2004_Evt1 event in the Socheon catchment was also acceptable. 

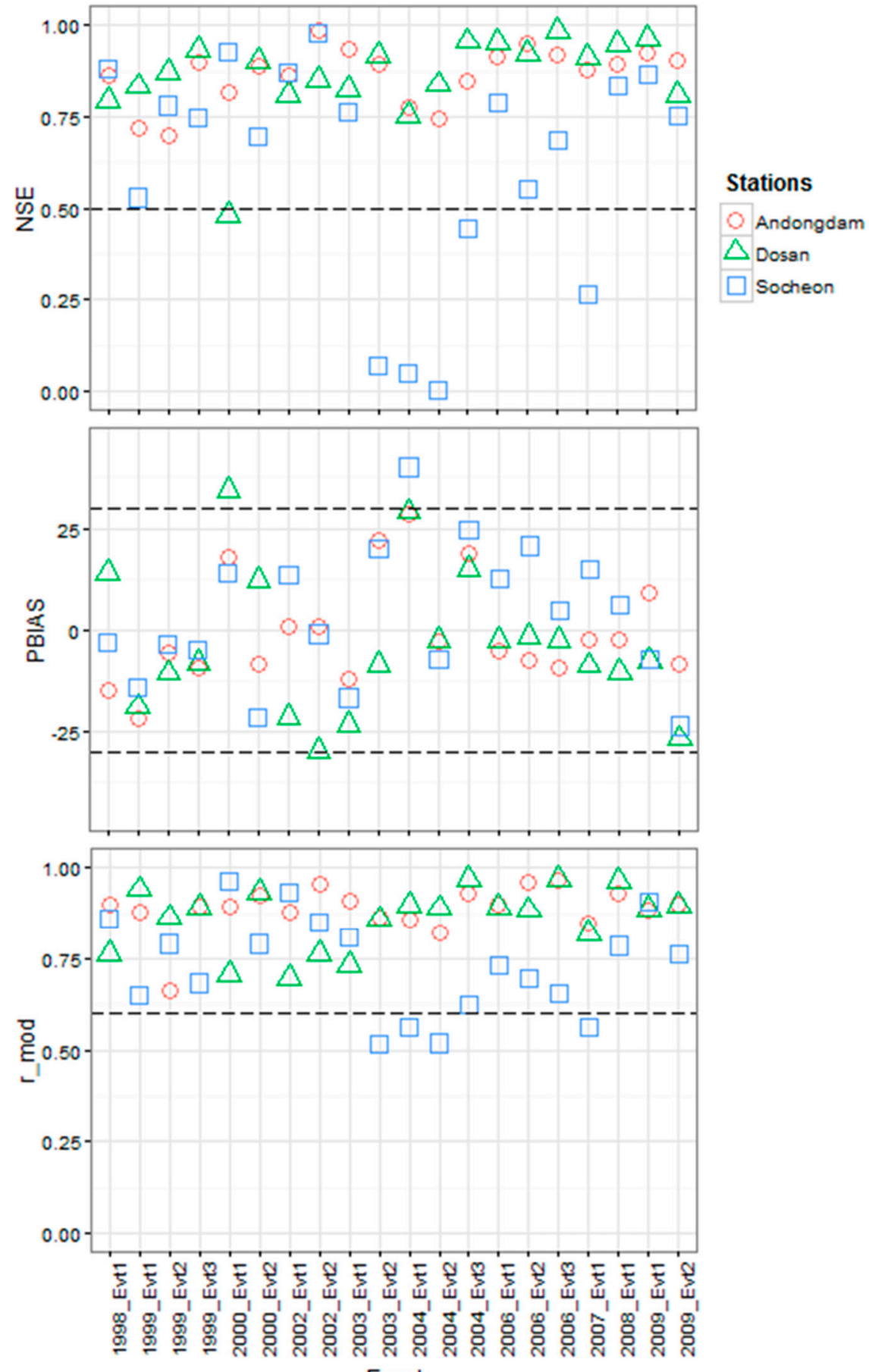

Event

Figure 5. Model performance evaluation statistics of the Nash-Sutcliffe efficiency (NSE), percent bias (PBIAS), and $r_{\text {mod }}$ (r_mod) for the calibration (Andongdam) and validation (Dosan and Socheon) catchments for 20 events. The black dashed lines represent the acceptance boundaries of the performance evaluation statistics: NSE $>0.5, \mathrm{PBIAS} \pm 30 \%$, and $r_{\bmod }>0.6$. 

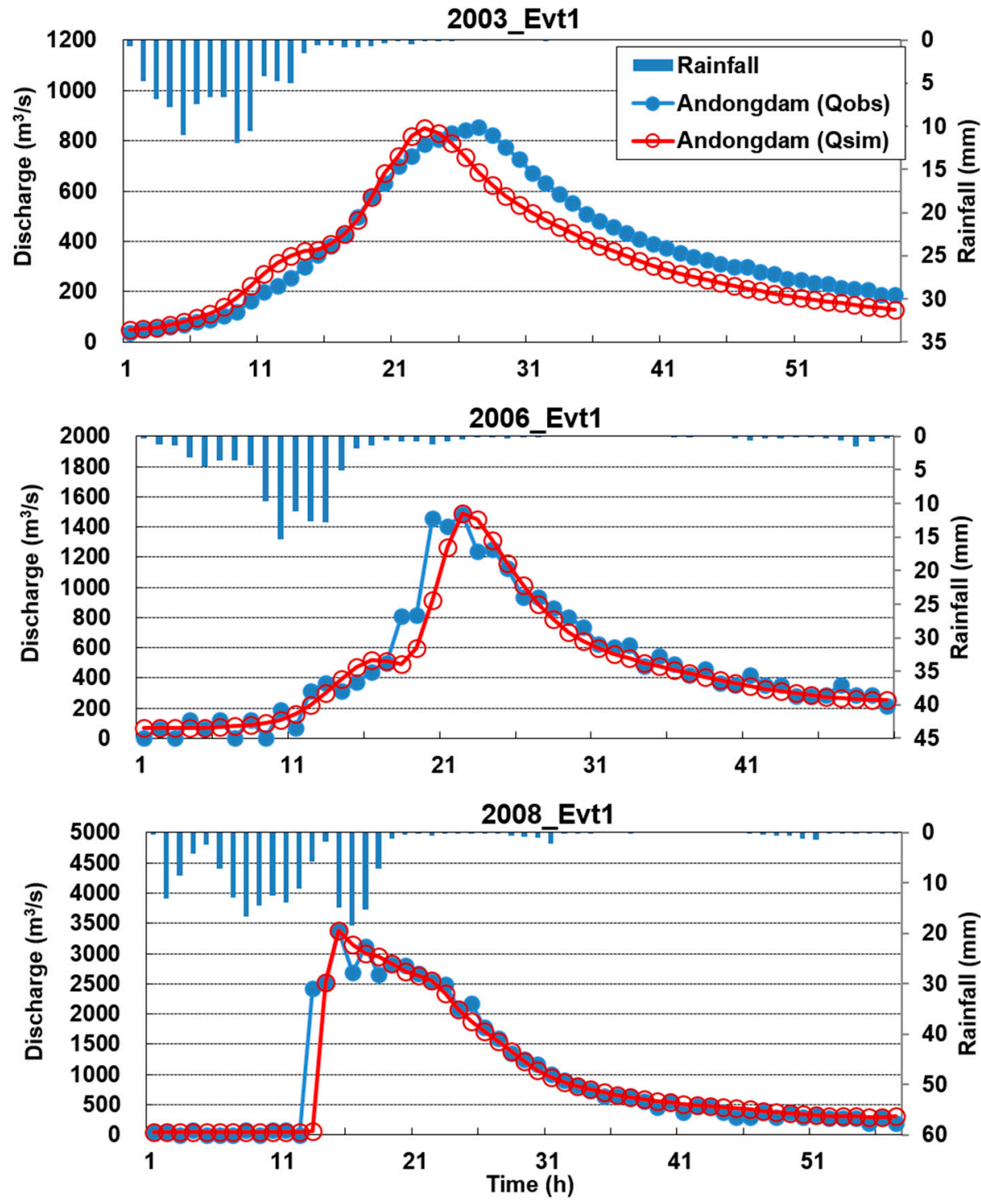

Figure 6. Observed hydrographs and simulated hydrographs by parameter calibration for three events in the Andongdam catchment.

\subsection{Estimation of the Relationship between the Runoff Coefficient, Runoff Ratio, Rainfall Intensity Ratios, and CN}

The estimated relationship between the important factors $C, C_{r}, R 1, R 2$, and $\mathrm{CN}$ using the stepwise multiple regression method is:

$$
C=5.2 C_{r} \frac{R 1^{0.19}}{R 2^{0.21} \mathrm{CN}^{0.37}}
$$

Figure 7 shows the values of $C$ and $C_{\text {sim }}$ for all 50 catchments ("All catchments") and the five selected catchments (Andongdam, Dosan, WP21, Socheon, and WP43) using 20 flood events. $C$ was calculated using the outputs of GRM model as described in Section 3.2. $C_{\text {sim }}$ was calculated using Equation (21), where $C_{r}$ was calculated using Equation (18). $C$ and $C_{\text {sim }}$ are very consistent in "All catchments", except for two outliers, and the r-squared value between them (Table 1) is high (0.9). The results in five selected catchments also show a good agreement with minor dispersion (Figure 7). Table 1 shows that most of the catchments' results have good r-squared values above 0.70 , except for four catchments (WP12, WP 28, WP42, and WP50). Therefore, Equation (21) can be used to calculate the $C$ values for these catchments, which include the ungauged catchments. 

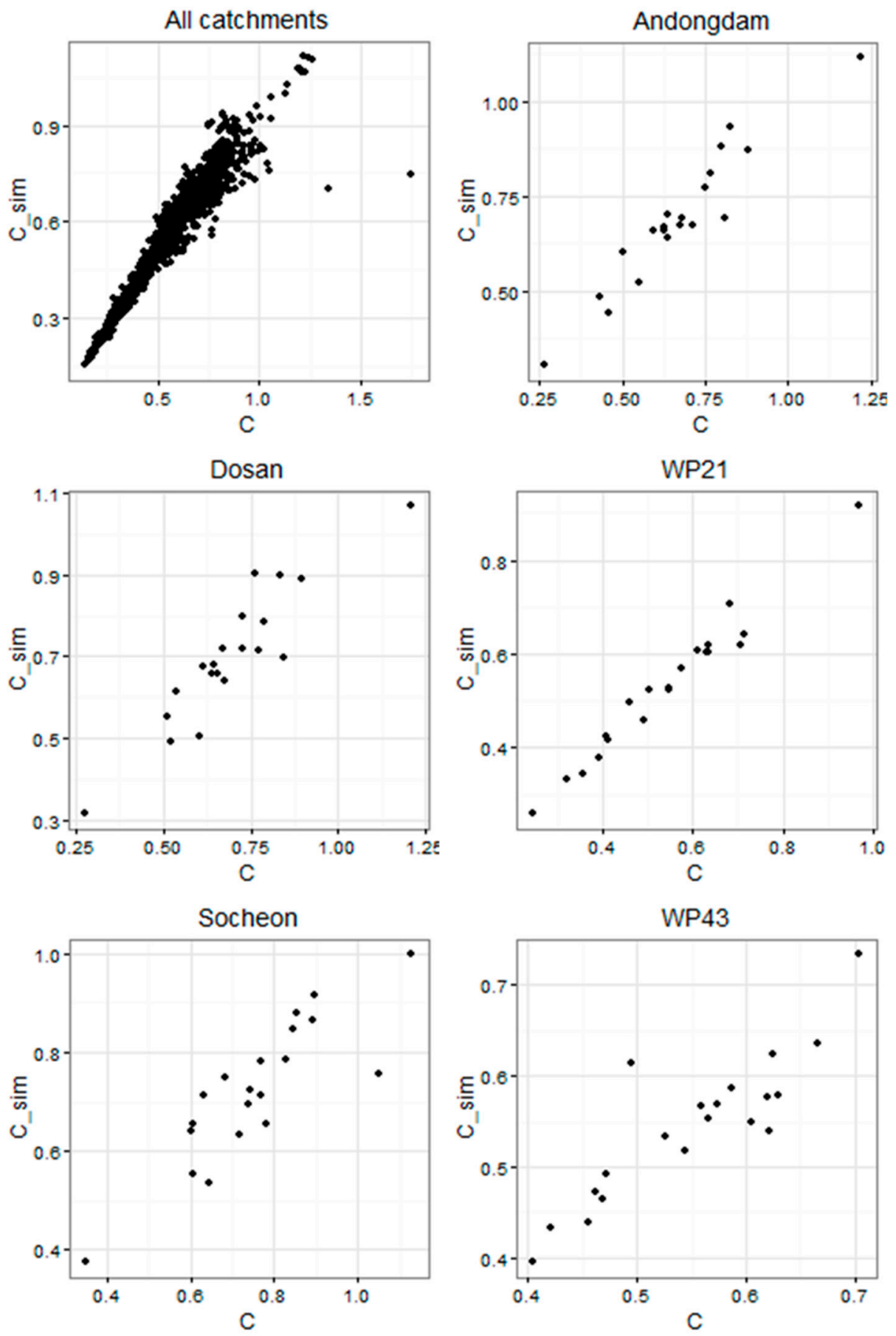

Figure 7. Comparison of the runoff coefficient $(C)$ and the simulated runoff coefficient (C_sim), which are based on the relationship between $C, C_{r}, R 1, R 2$, and $\mathrm{CN}$. 
Table 1. R-squared values for the runoff coefficient $(C)$ and simulated runoff coefficient $\left(C_{\text {sim }}\right)$ values.

\begin{tabular}{cccc}
\hline Catchment & R-Squared $\left(\boldsymbol{C}\right.$ and $\left.\boldsymbol{C}_{\text {sim }}\right)$ & Catchment & R-Squared $\left(\boldsymbol{C}\right.$ and $\left.\boldsymbol{C}_{\text {sim }}\right)$ \\
\hline Andongdam & 0.91 & WP26 & 0.84 \\
WP2 & 0.99 & WP27 & 0.97 \\
WP3 & 0.90 & WP28 & 0.68 \\
WP4 & 0.93 & Socheon & 0.73 \\
WP5 & 0.92 & WP30 & 0.84 \\
WP6 & 0.86 & WP31 & 0.71 \\
WP7 & 0.91 & WP32 & 0.75 \\
WP8 & 0.92 & WP33 & 0.98 \\
WP9 & 0.98 & WP34 & 0.99 \\
WP10 & 0.85 & WP35 & 0.76 \\
WP11 & 0.86 & WP36 & 0.96 \\
WP12 & 0.45 & WP37 & 0.97 \\
Dosan & 0.84 & WP38 & 0.90 \\
WP14 & 0.95 & WP40 & 0.92 \\
WP15 & 0.83 & WP41 & 0.87 \\
WP16 & 0.87 & WP42 & 0.79 \\
WP17 & 0.85 & WP43 & 0.51 \\
WP18 & 0.95 & WP44 & 0.76 \\
WP19 & 0.98 & WP45 & 0.86 \\
WP20 & 0.93 & WP46 & 0.80 \\
WP21 & 0.97 & WP47 & 0.79 \\
WP22 & 0.79 & WP48 & 0.82 \\
WP23 & 0.81 & WP49 & 0.83 \\
WP24 & 0.84 & WP50 & 0.80 \\
WP25 & 0.84 & & 0.55 \\
All catchments & 0.90 & &
\end{tabular}

4.3. Estimation of the Peak Flow Using the Relationship between the Runoff Coefficient, Runoff Ratio, Rainfall Intensity Ratios, and $\mathrm{CN}$

The correlation of $q_{\text {peak }}$ and $q_{\text {peak_sim }}$ is shown in Figure 8 and Table 2, and the correlation was significant. $q_{\text {peak }}$ was calculated using the outputs of the GRM as described in Section 3.2 and $q_{\text {peak }}$ sim was calculated by Equation (20) as described in Section 3.3. The agreement between $q_{\text {peak }}$ and $q_{\text {peak_sim }}$ is better than that of $C$ and $C_{s i m}$ in Figure 7 (compare the dispersion of the runoff coefficients and peak flows in Figures 7 and 8, respectively). Table 2 details the improved r-squared values compared to Table 1, especially for WP42 and WP50. Although WP12 and WP28 have r-squared values below 0.90, the values were still reasonable (greater than 0.79). Table 3 lists the NSE values for $q_{\text {peak }}$ and $q_{\text {peak }}$ sim for each of the 50 catchments and the aggregated 50 catchments ("All catchments"). The NSE value in "All catchments" is as high as 0.97. In most catchments, except for three (WP12, WP17, and WP28), NSE values are above 0.9 with a mean of 0.97 , which represents a very good correlation. The three catchments WP12, WP17, and WP28 show acceptable NSE values above 0.75 . 

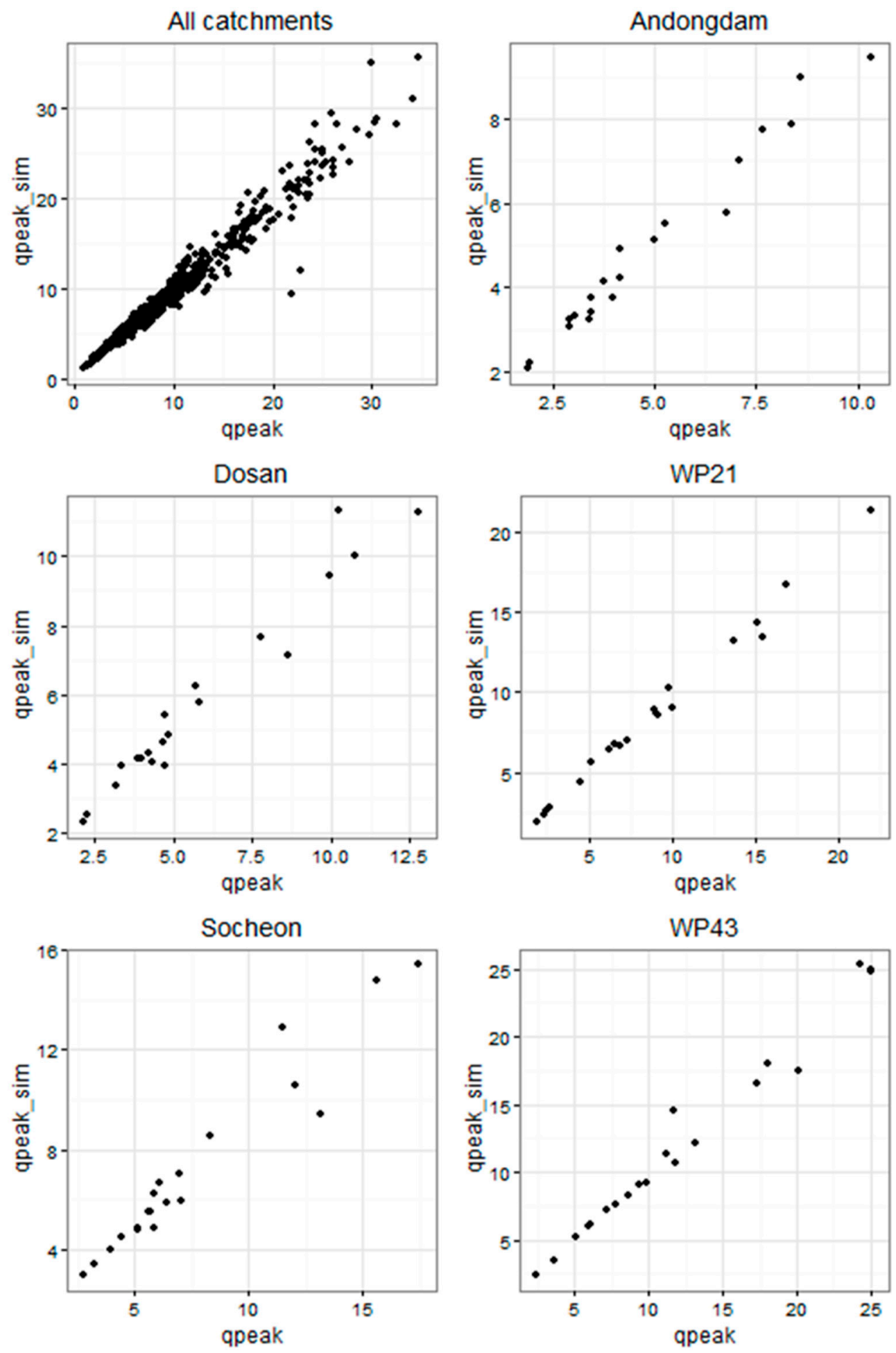

Figure 8. Comparison of the peak flow (qpeak) and the simulated peak flow (qpeak_sim) based on the rational method and simulated $C\left(C_{\text {sim }}\right)$. 
Table 2. R-squared values for the peak flow $\left(q_{\text {peak }}\right)$ and simulated peak flow $\left(q_{\text {peak_sim }}\right)$.

\begin{tabular}{cccc}
\hline Catchment & R-Squared $\left(q_{\text {peak }}\right.$ and $\left.q_{\text {peak_sim }}\right)$ & Catchment & R-Squared $\left(q_{\text {peak }}\right.$ and $\left.q_{\text {peak_sim }}\right)$ \\
\hline Andongdam & 0.972 & WP26 & 0.965 \\
WP2 & 0.994 & WP27 & 0.994 \\
WP3 & 0.971 & WP28 & 0.787 \\
WP4 & 0.976 & Socheon & 0.933 \\
WP5 & 0.987 & WP30 & 0.983 \\
WP6 & 0.957 & WP31 & 0.990 \\
WP7 & 0.989 & WP32 & 0.948 \\
WP8 & 0.990 & WP33 & 0.999 \\
WP9 & 0.994 & WP34 & 0.996 \\
WP10 & 0.962 & WP35 & 0.962 \\
WP11 & 0.964 & WP36 & 0.989 \\
WP12 & WP37 & 0.996 \\
Dosan & 0.851 & WP38 & 0.987 \\
WP14 & 0.956 & WP39 & 0.975 \\
WP15 & 0.984 & WP40 & 0.982 \\
WP16 & 0.955 & WP41 & 0.978 \\
WP17 & 0.991 & WP42 & 0.987 \\
WP18 & 0.941 & WP43 & 0.979 \\
WP19 & 0.989 & WP44 & 0.986 \\
WP20 & 0.990 & WP45 & 0.972 \\
WP21 & 0.989 & WP46 & 0.990 \\
WP22 & 0.992 & WP47 & 0.972 \\
WP23 & 0.945 & WP48 & 0.964 \\
WP24 & 0.954 & WP49 & 0.975 \\
WP25 & 0.983 & WP50 & 0.985 \\
All catchments & 0.986 & & \\
\hline & 0.969 & & \\
\hline
\end{tabular}

Table 3. NSE values for the peak flow $\left(q_{\text {peak }}\right)$ and simulated peak flow $\left(q_{\text {peak_sim }}\right)$.

\begin{tabular}{cccccc}
\hline Catchment & NSE & Catchment & NSE & Catchment & NSE \\
\hline Andongdam & 0.97 & WP18 & 0.99 & WP35 & 0.96 \\
WP2 & 0.99 & WP19 & 0.99 & WP36 & 0.99 \\
WP3 & 0.97 & WP20 & 0.96 & WP37 & 0.99 \\
WP4 & 0.97 & WP21 & 0.99 & WP38 & 0.98 \\
WP5 & 0.99 & WP22 & 0.94 & WP39 & 0.97 \\
WP6 & 0.95 & WP23 & 0.95 & WP40 & 0.95 \\
WP7 & 0.98 & WP24 & 0.97 & WP41 & 0.97 \\
WP8 & 0.98 & WP25 & 0.98 & WP42 & 0.98 \\
WP9 & 0.99 & WP26 & 0.97 & WP43 & 0.98 \\
WP10 & 0.96 & WP27 & 0.99 & WP44 & 0.93 \\
WP11 & 0.96 & WP28 & 0.76 & WP45 & 0.95 \\
WP12 & 0.75 & Socheon & 0.92 & WP46 & 0.97 \\
Dosan & 0.95 & WP30 & 0.96 & WP47 & 0.95 \\
WP14 & 0.98 & WP31 & 0.96 & WP48 & 0.95 \\
WP15 & 0.95 & WP32 & 0.95 & WP49 & 0.97 \\
WP16 & 0.99 & WP33 & 0.99 & WP50 & 0.93 \\
WP17 & 0.86 & WP34 & 0.99 & All catchments & 0.97 \\
\hline
\end{tabular}

Figure 9 compares the simulated peak flow $q_{\text {peak_sim }}$ with the observed $\left(q_{\text {peak_obs }}\right)$. The $q_{\text {peak_sim }}$ of the three catchments were highly correlated with the $q_{\text {peak_obs. }}$. Table 4 shows good r-squared values of the three catchments. While NSE values for the Andongdam and Dosan catchments were reasonable, the Socheon catchment had a lower value, which could be due to one large outlier shown in Figure 9. The authors inferred that the water level measurement error is the cause of the outlier, as described in Section 4.1. Therefore, it is determined that the peak flow in the ungauged catchments can be successfully calculated using the rational method, estimated relationship for $C_{\text {sim }}$ calculation, rainfall time series, and $\mathrm{CN}$. 

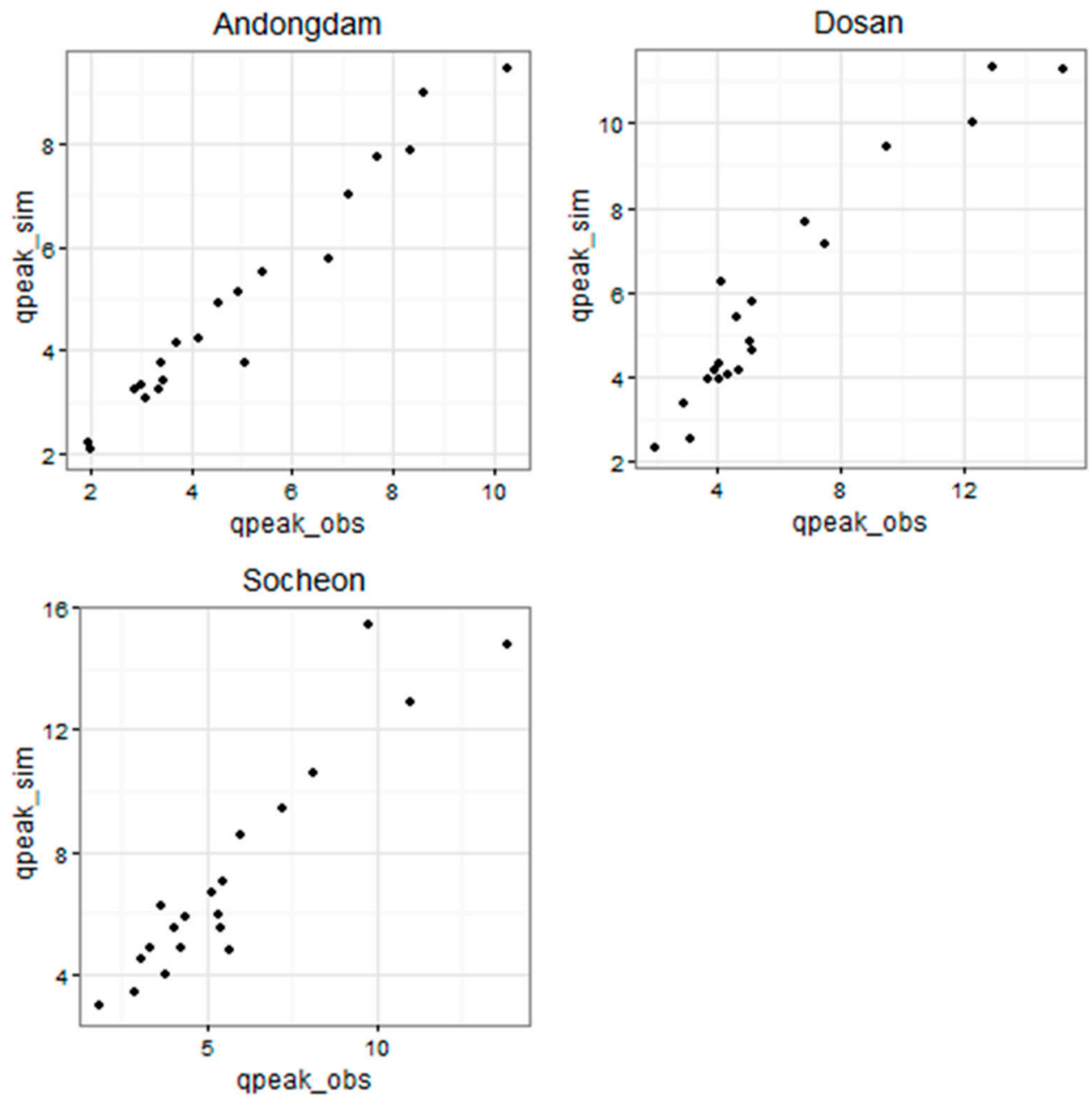

Figure 9. Comparison of the observed peak flow (qpeak_obs) and the simulated peak flow (qpeak_sim) based on the rational method and simulated $C\left(C_{\text {sim }}\right)$.

Table 4. R-squared and NSE values for the observed peak flow $\left(q_{\text {peak_obs }}\right)$ and simulated peak flow $\left(q_{\text {peak_sim }}\right)$.

\begin{tabular}{ccc}
\hline Catchment & R-Squared $\left(q_{\text {peak_obs }}\right.$ and $\left.q_{\text {peak_sim }}\right)$ & NSE \\
\hline Andongdam & 0.958 & 0.957 \\
Dosan & 0.915 & 0.876 \\
Socheon & 0.874 & 0.545 \\
\hline
\end{tabular}

This study described a method for estimating the peak flow in ungauged catchments using the relationship between the runoff coefficient and curve number without the need for repetitive hydrological simulation. Users can use this method by referring to the steps shown in Figure 4.

However, this study has the following limitations. The range of error of the simulated peak flow for ungauged catchments may depend on the performance of the selected rainfall-runoff model. Therefore, further research is required for lower uncertainty in peak flow simulation via parametric and structural uncertainty analysis of the rainfall-runoff model (e.g., [60-62]). In addition, this study used one distributed rainfall-runoff model. As remarked by Onyutha [63], the influence from the selection of a hydrological model among others can lead to large under- and/or over-estimations of extreme events. Therefore it is recommended that application of the methodology in this study for related future research work should comprise several hydrological models. During future studies, it will be possible to investigate the degree of difference between simulation results by various 
models, which model can be relied on, and the confidence interval of prediction of peak flow. Finally, frequency analysis was not addressed in this study. Some previous studies, such as Onyutha and Willems [64], performed regionalization of peak flows based on frequency analyses to yield quantiles at ungauged catchments. However, in this study, frequency analyses were not conducted. It is envisaged that application of the methodology in this study based on results from frequency analyses will improve the results of the peak flows for ungauged catchments with respect to the applicability for design of water resources applications. However, reliable peak flow data should be used to obtain reliable frequency analysis results. Therefore, uncertainty analysis and model comparison analysis should precede frequency analysis.

\section{Conclusions}

The aim of this study is to analyze the relationship between runoff coefficients and curve numbers, which have different theoretical origins, using rainfall and flow data generated by the SDE method for many ungauged catchments. Previous studies did not find the relationship between runoff coefficient and curve number using data from ungauged catchments.

In summary, the performances of the GRM flow simulations for the gauged catchments were adequate; therefore, we used the SDE method to generate hydrographs of the ungauged catchments in the study area. Using the hydrographs and rainfall time series data, runoff coefficients and curve numbers were calculated and then their relationship was estimated. The presented results showed that the simulated runoff coefficient $\left(C_{\text {sim }}\right)$ based on this relationship agrees well with $C$. In addition, the simulated peak flows $\left(q_{\text {peak_sim }}\right)$ using the rational method and $C_{\text {sim }}$ show a good correlation with the peak flows in the gauged and ungauged catchments. Therefore, the proposed method presented in this study allows researchers and engineers to easily calculate the peak flow of an ungauged catchment in practical applications.

Author Contributions: Conceptualization, N.W.K.; Methodology, N.W.K. and M.-J.S.; Software, M.-J.S.; Validation, N.W.K. and M.-J.S.; Formal Analysis, N.W.K. and M.-J.S.; Investigation, N.W.K. and M.-J.S.; Resources, M.-J.S.; Data Curation, M.-J.S.; Writing-Original Draft Preparation, N.W.K. and M.-J.S.; Writing-Review \& Editing, N.W.K. and M.-J.S.; Visualization, M.-J.S.; Supervision, N.W.K.; Project Administration, N.W.K.; Funding Acquisition, N.W.K.

Funding: This research was funded by the Korea Institute of Civil Engineering and Building Technology (grant number 20180374-001).

Acknowledgments: This research was supported by a grant from a Strategic Research Project (Development of Hydrological Safety Assessment System for Hydraulic Structures) funded by the Korea Institute of Civil Engineering and Building Technology. Authors appreciate the editors of the journal and the reviewers for their valuable comments and suggestions for improvements.

Conflicts of Interest: The authors declare no conflict of interest.

\section{Appendix A Tables Describing Selected Events, Model Parameters,} and Catchment Characteristics

Table A1. Period and peak rainfall of the 20 events.

\begin{tabular}{|c|c|c|c|c|c|}
\hline Event & Period ${ }^{[a]}$ & $\begin{array}{l}\text { Peak Rainfall } \\
(\mathrm{mm} / \mathrm{h})\end{array}$ & Event & Period & $\begin{array}{l}\text { Peak Rainfall } \\
(\mathrm{mm} / \mathrm{h})\end{array}$ \\
\hline 1998_Evt1 & 1998.08.14:19-1998.08.17:23 & 16.8 & 2004_Evt1 & 2004.06.19:04-2004.06.23:03 & 11.0 \\
\hline 1999_Evt1 & 1999.08.02:13-1999.08.05:04 & 26.1 & 2004_Evt2 & 2004.07.15:09-2004.07.19:02 & 15.0 \\
\hline 1999_Evt2 & 1999.09.19:20-1999.09.22:01 & 20.7 & 2004_Evt3 & 2004.08.17:19-2004.08.20:22 & 19.4 \\
\hline 1999_Evt3 & 1999.09.23:04-1999.09.25:19 & 14.8 & 2006_Evt1 & 2006.07.10:07-2006.07.12:08 & 15.3 \\
\hline 2000_Evt1 & 2000.09.13:01-2000.09.15:18 & 7.0 & 2006_Evt2 & 2006.07.15:14-2006.07.17:10 & 13.6 \\
\hline 2000_Evt2 & 2000.09.16:04-2000.09.18:04 & 17.4 & 2006_Evt3 & 2006.07.28:04-2006.07.31:01 & 9.3 \\
\hline 2002_Evt1 & 2002.08.05:20-2002.08.09:16 & 20.6 & 2007_Evt1 & 2007.09.01:02-2007.09.03:17 & 8.2 \\
\hline 2002_Evt2 & 2002.08.30:23-2002.09.02:04 & 27.1 & 2008_Evt1 & 2008.07.24:19-2008.07.27:03 & 18.4 \\
\hline 2003_Evt1 & 2003.06.27:09-2003.06.29:18 & 11.9 & 2009_Evt1 & 2009.07.11:21-2009.07.14:08 & 14.7 \\
\hline 2003_Evt2 & 2003.09.11:24-2003.09.15:01 & 33.0 & 2009_Evt2 & 2009.07.14:15-2009.07.16:22 & 26.3 \\
\hline
\end{tabular}


Table A2. Description of the GRM model parameters.

\begin{tabular}{|c|c|c|c|c|c|}
\hline No. & Parameter & Unit & Range & Description & Calibration \\
\hline 1 & IniSaturation & - & $0-1$ & Initial soil saturation ratio & Yes \\
\hline 2 & MinSlopeLdSrf & - & $0.0001-0.04$ & Minimum slope of land surface & Yes \\
\hline 3 & MinSlopeChBed & - & $0.001-0.04$ & Minimum slope of channel bed & Yes \\
\hline 4 & MinChBaseWidth & $\mathrm{m}$ & - & Minimum channel width & Yes \\
\hline 5 & ChRoughness & - & $0.025-0.15$ & Channel roughness coefficient & Yes \\
\hline 6 & IniFlow & CMS & - & Initial stream flow & No \\
\hline 9 & CalCoefPorosity & - & $0-4$ & Soil porosity & No \\
\hline 10 & CalCoefWFSuctionHead & - & $0-4$ & Soil wetting front suction head & No \\
\hline 11 & CalCoefHydraulicK & - & $0-4$ & Soli hydraulic conductivity & No \\
\hline 12 & CalCoefSoilDepth & - & $0-4$ & Soil depth & No \\
\hline
\end{tabular}

Table A3. Size of area, average slope, and channel length of the catchment for the 50 catchments.

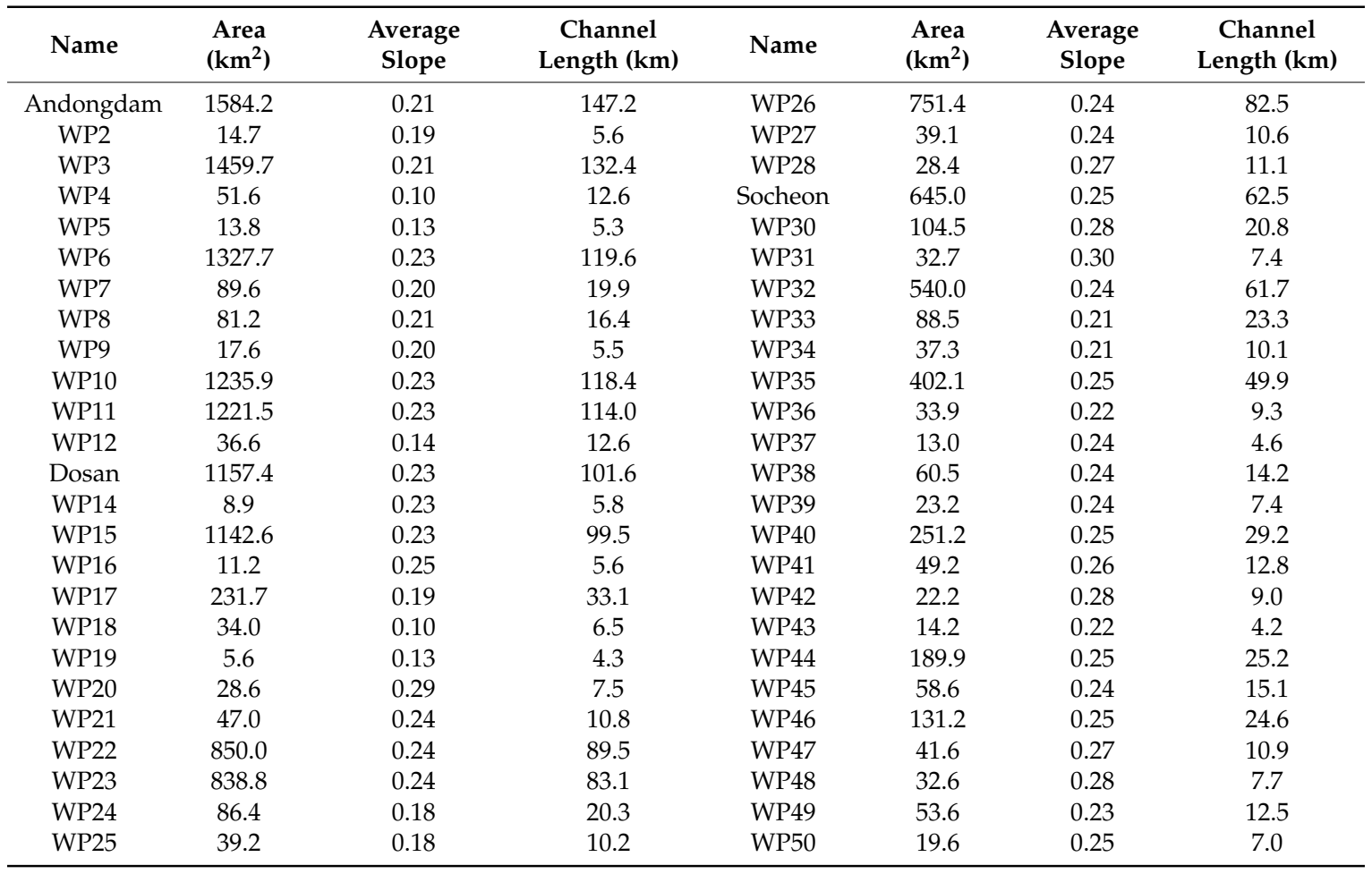

\section{References}

1. Bárdossy, A. Calibration of hydrological model parameters for ungauged catchments. Hydrol. Earth Syst. Sci. Discuss. 2007, 11, 703-710. [CrossRef]

2. Bhaskar, N.R.; Parida, B.P.; Nayak, A.K. Flood estimation for ungauged catchments using the GIUH. J. Water Res. Plan. Manag. 1997, 123, 228-238. [CrossRef]

3. Cunnane, C. Methods and merits of regional flood frequency analysis. J. Hydrol. 1988, 100, $269-290$. [CrossRef]

4. Hosking, J.R.M.; Wallis, J.R. Some statistics useful in regional frequency analysis. Water Resour. Res. 1993, 29, 271-281. [CrossRef]

5. Burn, D.H.; Zrinji, Z.; Kowalchuk, M. Regionalization of catchments for regional flood frequency analysis. J. Hydrol. Eng. 1997, 2, 76-82. [CrossRef]

6. Stedinger, J.R.; Tasker, G.D. Regional hydrologic analysis: 1. Ordinary, weighted, and generalized least squares compared. Water Resour. Res. 1985, 21, 1421-1432. [CrossRef]

7. Potter, K.W.; Faulkner, E.B. Catchment response time as a predictor of flood quantiles. J. Am. Water Resour. Assoc. 1987, 23, 857-861. [CrossRef] 
8. Tasker, G.D.; Driver, N.E. Nationwide regression models for predicting urban runoff water quality at unmonitored sites. J. Am. Water Resour. Assoc. 1988, 24, 1091-1101. [CrossRef]

9. Vogel, R.M.; Kroll, C.N. Generalized low-flow frequency relationships for ungaged sites in Massachusetts. J. Am. Water Resour. Assoc. 1990, 26, 241-253. [CrossRef]

10. Viviroli, D.; Mittelbach, H.; Gurtz, J.; Weingartner, R. Continuous simulation for flood estimation in ungauged mesoscale catchments of Switzerland-Part II: Parameter regionalisation and flood estimation results. J. Hydrol. 2009, 377, 208-225. [CrossRef]

11. Sahoo, B.; Chatterjee, C.; Raghuwanshi, N.S.; Singh, R.; Kumar, R. Flood estimation by GIUH-based Clark and Nash models. J. Hydraul. Eng. 2006, 11, 515-525. [CrossRef]

12. Oudin, L.; Kay, A.; Andréassian, V.; Perrin, C. Are seemingly physically similar catchments truly hydrologically similar? Water Resour. Res. 2010, 46, W11558. [CrossRef]

13. Rodríguez-Iturbe, I.; Valdés, J.B. The geomorphologic structure of hydrologic response. Water Resour. Res. 1979, 15, 1409-1420. [CrossRef]

14. Jain, S.K.; Singh, R.D.; Seth, S.M. Design flood estimation using GIS supported GIUHApproach. Water Resour. Manag. 2000, 14, 369-376. [CrossRef]

15. Kumar, R.; Chatterjee, C.; Singh, R.D.; Lohani, A.K.; Kumar, S. Runoff estimation for an ungauged catchment using geomorphological instantaneous unit hydrograph (GIUH) models. Hydrol. Process. 2007, 21, 1829-1840. [CrossRef]

16. Cole, S.J.; Moore, R.J. Distributed hydrological modelling using weather radar in gauged and ungauged basins. Adv. Water Resour. 2009, 32, 1107-1120. [CrossRef]

17. Smith, M.B.; Koren, V.; Zhang, Z.; Zhang, Y.; Reed, S.M.; Cui, Z.; Moreda, F.; Cosgrove, B.A.; Mizukami, N.; Anderson, E.A. DMIP 2 Participants. Results of the DMIP 2 Oklahoma experiments. J. Hydrol. 2012, 418-419, 17-48. [CrossRef]

18. U.S. Soil Conservation Service (SCS). Hydrology. In National Engineering Handbook; United States Government Printing Office: Washington, DC, USA, 1972.

19. Chow, V.T.; Maidment, D.R.; Mays, L.W. Applied Hydrology; McGraw-Hill: New York, NY, USA, 1988.

20. Kuichling, E. The relation between the rainfall and the discharge of sewers in populous districts. Trans. Am. Soc. Civ. Eng. 1889, 20, 1-56.

21. McCuen, R.H.; Bondelid, T.R. Relation between curve number and runoff coefficient. J. Irrig. Drain. Div.-ASCE 1981, 107, 395-400.

22. Kim, N.W.; Shin, M.J. Experimental study of rainfall spatial variability effect on peak flow variability using a data generation method. J. Korea Water Resour. Assoc. 2017, 50, 359-371. (In Korean)

23. Nash, J.E.; Sutcliffe, J.V. River flow forecasting through conceptual models part I-A discussion of principles. J. Hydrol. 1970, 10, 282-290. [CrossRef]

24. Legates, D.R.; McCabe, G.J. Evaluating the use of "goodness-of-fit" measures in hydrologic and hydroclimatic model validation. Water Resour. Res. 1999, 35, 233-241. [CrossRef]

25. Krause, P.; Boyle, D.P.; Bäse, F. Comparison of different efficiency criteria for hydrological model assessment. Adv. Geosci. 2005, 5, 89-97. [CrossRef]

26. McCuen, R.H.; Snyder, W.M. A proposed index for comparing hydrographs. Water Resour. Res. 1975, 11, 1021-1024. [CrossRef]

27. American Society of Civil Engineers (ASCE). Criteria for evaluation of watershed models. J. Irrig. Drain. Eng. 1993, 119, 429-442. [CrossRef]

28. Moriasi, D.N.; Arnold, J.G.; Van Liew, M.W.; Bingner, R.L.; Harmel, R.D.; Veith, T.L. Model evaluation guidelines for systematic quantification of accuracy in watershed simulations. Trans. ASABE 2007, 50, 885-900. [CrossRef]

29. Smith, M.B.; Seo, D.J.; Koren, V.I.; Reed, S.M.; Zhang, Z.; Duan, Q.; Moreda, F.; Cong, S. The distributed model intercomparison project (DMIP): Motivation and experiment design. J. Hydrol. 2004, 298, 4-26. [CrossRef]

30. Gupta, H.V.; Sorooshian, S.; Yapo, P.O. Status of automatic calibration for hydrologic models: Comparison with multilevel expert calibration. J. Hydrol. Eng. 1999, 4, 135-143. [CrossRef]

31. Choi, Y.S.; Choi, C.K.; Kim, H.S.; Kim, K.T.; Kim, S. Multi-site calibration using a grid-based event rainfall-runoff model: A case study of the upstream areas of the Nakdong River basin in Korea. Hydrol. Process. 2015, 29, 2089-2099. [CrossRef] 
32. Horton, R.E. The role of infiltration of hydrologic cycle. Trans. Am. Geophys. Union 1933, 14, 446-460. [CrossRef]

33. Dunne, T.; Black, R.D. An experimental investigation of runoff production in permeable soils. Water Resour. Res. 1970, 6, 478-490. [CrossRef]

34. Beven, K.J.; Kirkby, M.J. A physically based, variable contributing area model of basin hydrology. Hydrol. Sci. J. 1979, 24, 43-69. [CrossRef]

35. Freeze, R.A.; Cherry, J.A. Groundwater; Prentice Hall Inc.: Upper Saddle River, NY, USA, 1979; pp. 15-236.

36. Choi, Y.S.; Korea Institute of Civil Engineering and Building Technology, Gyeonggi-do, Korea. Personal communication, 2016.

37. Bathurst, J.C. Sensitivity analysis of the Systeme Hydrologique Europeen for an upland catchment. J. Hydrol. 1986, 87, 103-123. [CrossRef]

38. Choi, Y.S.; Kim, K.T. Grid based Rainfall-runoff Model User's Manual. Korea Institute of Civil Engineering and Building Technology, 2017; pp. 1-39. Available online: https://github.com/floodmodel/GRM (accessed on 3 August 2017).

39. Abbott, M.B.; Bathurst, J.C.; Cunge, J.A.; O'Connell, P.E.; Rasmussen, J. An introduction to the European Hydrological System-Systeme Hydrologique Europeen, "SHE", 1: History and philosophy of a physically-based, distributed modelling system. J. Hydrol. 1986, 87, 45-59. [CrossRef]

40. Refsgaard, J.C.; Storm, B. Construction, calibration and validation of hydrological models. In Distributed Hydrological Modelling; Abbott, M.B., Refsgaard, J.C., Eds.; Kluwer Academic: Dordrecht, The Netherlands, 1996; pp. 41-54.

41. Eckhardt, K.; Arnold, J.G. Automatic calibration of a distributed catchment model. J. Hydrol. 2001, 251, 103-109. [CrossRef]

42. Lee, H.; McIntyre, N.; Wheater, H.; Young, A. Selection of conceptual models for regionalisation of the rainfall-runoff relationship. J. Hydrol. 2005, 312, 125-147. [CrossRef]

43. Sahoo, G.B.; Ray, C.; De Carlo, E.H. Calibration and validation of a physically distributed hydrological model, MIKE SHE, to predict streamflow at high frequency in a flashy mountainous Hawaii stream. J. Hydrol. 2006, 327, 94-109. [CrossRef]

44. Parajka, J.; Blöschl, G.; Merz, R. Regional calibration of catchment models: Potential for ungauged catchments. Water Resour. Res. 2007, 43, W06406. [CrossRef]

45. Klemeš, V. Operational testing of hydrological simulation models. Hydrol. Sci. J. 1986, 31, 13-24. [CrossRef]

46. Natural Environment Research Council (NERC). Estimation of Flood Volumes over Different Durations; Flood Studies Report; Natural Environment Research Council: Wallingford, UK, 1975; Volume 1, Chapter 5; pp. 243-264.

47. Ashkar, F. Partial Duration Series Models for Flood Analysis. Ph.D. Thesis, École Polytechnique de Montréal, Montréal, QC, Canada, 1980.

48. Javelle, P.; Ouarda, T.B.; Lang, M.; Bobée, B.; Galéa, G.; Grésillon, J.M. Development of regional flood-duration-frequency curves based on the index-flood method. J. Hydrol. 2002, 258, 249-259. [CrossRef]

49. Cunderlik, J.M.; Ouarda, T.B. Regional flood-duration-frequency modeling in the changing environment. J. Hydrol. 2006, 318, 276-291. [CrossRef]

50. Balocki, J.B.; Burges, S.J. Relationships between n-day flood volumes for infrequent large floods. J. Water Resour. Plan. Manag. 1994, 120, 794-818. [CrossRef]

51. Sherwood, J.M. Estimation of volume-duration-frequency relations of ungaged small urban streams in ohio1. J. Am. Water Resour. Assoc. 1994, 30, 261-269. [CrossRef]

52. Meunier, M. Regional flow-duration-frequency model for the tropical island of Martinique. J. Hydrol. 2001, 247, 31-53. [CrossRef]

53. Javelle, P.; Ouarda, T.B.; Bobée, B. Spring flood analysis using the flood-duration-frequency approach: Application to the provinces of Quebec and Ontario, Canada. Hydrol. Process. 2003, 17, 3717-3736. [CrossRef]

54. Cunderlik, J.M.; Ouarda, T.B. Regional flood-rainfall duration-frequency modeling at small ungaged sites. J. Hydrol. 2007, 345, 61-69. [CrossRef]

55. Kim, N.W. A Comparative Study on the Evaluation of Rainstorm Runoff Characteristics at Ungauged Location-On the Rational Method; Research Report Contribution No. 94-WR-112; Korea Institute of Construction Technology: Gyeonggi-do, Korea, 1994; 280p. (In Korean) 
56. Boyd, M.J. A storage-routing model relating drainage basin hydrology and geomorphology. Water Resour. Res. 1978, 14, 921-928. [CrossRef]

57. D'Odorico, P.; Rigon, R. Hillslope and channel contributions to the hydrologic response. Water Resour. Res. 2003, 39, 1113. [CrossRef]

58. U.S. Department of Agriculture, Natural Resources Conservation Service (USDA-NRCS). Part 630: Hydrology, National Engineering Handbook; US Government Printing Office: Washington, DC, USA, 2004.

59. Hawkins, R.H. Improved prediction of storm runoff in mountain watershed. J. Irrig. Drain. Div.-ASCE 1973, 99, 519-523.

60. Shin, M.J.; Guillaume, J.H.; Croke, B.F.; Jakeman, A.J. Addressing ten questions about conceptual rainfall-runoff models with global sensitivity analyses in R. J. Hydrol. 2013, 503, 135-152. [CrossRef]

61. Shin, M.J.; Guillaume, J.H.; Croke, B.F.; Jakeman, A.J. A review of foundational methods for checking the structural identifiability of models: Results for rainfall-runoff. J. Hydrol. 2015, 520, 1-16. [CrossRef]

62. Walega, A.; Ksiazek, L. Influence of rainfall data on the uncertainty of flood simulation. Soil Water Res. 2016, 11. [CrossRef]

63. Onyutha, C. Influence of hydrological model selection on simulation of moderate and extreme flow events: A case study of the Blue Nile Basin. Adv. Meteorol. 2016, 2016. [CrossRef]

64. Onyutha, C.; Willems, P. Empirical statistical characterization and regionalization of amplitude-duration-frequency curves for extreme peak flows in the Lake Victoria Basin, East Africa. Hydrol. Sci. J. 2015, 60, 997-1012. [CrossRef]

(C) 2018 by the authors. Licensee MDPI, Basel, Switzerland. This article is an open access article distributed under the terms and conditions of the Creative Commons Attribution (CC BY) license (http://creativecommons.org/licenses/by/4.0/). 